\title{
The effect of tofu cake as an additional feed on local male sheep's water consumption and their physiological response
}

\author{
Wayan Sukarya Dilaga ${ }^{1}$, R. Adiwinarti \\ Cattle Science Department, Faculty of Animal Agriculture, Diponegoro University \\ Jl. Prof. Soedarto, SH. Kampus Tembalang, Semarang, Indonesia, 50239 \\ ${ }^{1}$ sukaryadilaga@yahoo.com
}

\begin{abstract}
Feeds are very important for the growth of animals due to it is contained almost all nutrients needed by the animals. Feeds are not only influence the animal growth but also their physiological response. The objective of this research was to investigate the effect of tofu cake as an additional feed replacing commercial concentrate on local male sheep's water consumption and their physiological response such as body temperature, pulse, and rate of exhalation. The selected 15 local male sheep (in the age of 8-9 month with initial weight $12.53 \pm 1.19 \mathrm{~kg}$ ) were housed individually in cage for about 14 weeks include 4 weeks adaptation period and 10 weeks experiment.The experiment was conducted using completely randomized design with 3 different treatments and 5 times repetition; $\mathrm{T}_{0}=$ ad libitum grass field + commercial concentrate, $\mathrm{T}_{1}=$ ad libitum grass field + wet tofu cake, $\mathrm{T}_{2}=$ ad libitum grass field + dried tofu cake, and water were provided in ad libitum method. Data analysis was done using analysis of variance (ANOVA) followed by Duncan's multiple range test. The result shown that dried tofu cake as an additional feed replacing commercial concentrate was able to increasing the water consumption of local male sheep. Meanwhile the physiological test performed stable in the present of wet or dried tofu cake.
\end{abstract}

Keywords - alternative feed, physiological response of male sheep

\section{INTRODUCTION}

The nutrition of farm animals especially sheep is associated with several function such as a source of energy for all the life processes, as structural material for building and maintaining the body structure, and as material for the production of nutrient, milk, and meat $[\mathbf{1}, \mathbf{2}, \mathbf{3}]$. Feed supplies needs to meet the amount of livestock's requirement, easy to obtain, available during the year, not expensive and not vie with human food requirement to improve the productivity of the ranch and decrease the production cost especially for smallholder farmer. The primary nutrition source of ruminant like sheep is fibrous feed, which contain mostly carbohydrate and less protein. Farmers usually give additional feed to fulfill the protein and other nutrients needed by the sheep.

There have been many studies on the use of byproducts of agricultural industry for composing of animal diet, such as palm oil [4], white radish root [5], 'tempeh' cake [6]. Tofu cake is by-product of tofu (soybean curd) industry, has been used widely for animal diet component in farm level, due to its high content of protein and carbohydrate $[7,8]$. Tofu cake is available in two forms, wet and dried. Wet tofu cake usually cannot stand to organic microbial decomposition, so that dried form is better for long time storage [9].

Refer to above; tofu cake can be an alternative to replacing the expensive concentrate as an additional feed. Some researchers have studied the possibility and the effect of tofu cake as an additional feed in rabbit [10], Muscovy duck [11, 12], and it is conclude that tofu cake can influence the performance of growing period to be more better. Meanwhile, investigation of the tofu cake effect as an additional food on local male sheep still lack in literature.
Sheep can be claimed as a healthy sheep from parameters such as the water consumption and physiological response. Water consumption will increase if the abundant minerals and protein contained in the feed consumed by the animal $[2,13]$. On the other hand, physiological response shown by the animal has to be the same as the standard physiological data. If there were deviation from the standard, there might be some organs of animal worked unusually [14]. The increment of energy production on the animal's body above optimum standard will followed by the change of physiological condition such as exhalation frequency, pulse and body temperature [13]. Technique of feeding and variant of feed can influence the water consumption and physiological response.

The scope of this work is two folds; first to investigate the effect of tofu cake as an additional feed on local male sheep's water consumption. The second objective is to examine physiological response of local male sheep on the addition of tofu cake in their feed.

\section{MATERIAL AND METHODS}

The experiments were conducted in accredited experimental barns of Department Cattle Science, Faculty of Animal Agriculture, Diponegoro University. Local male sheep selected for the experiment are in the age of 8-9 month with initial weight $12.53 \pm 1.19 \mathrm{~kg}$. The selected 15 local male sheep were housed individually in cage with $1.2 \times 0.5 \times 0.8$ $\mathrm{m} 3$ dimension. These experiments were divided into 3 parts: (a) preparation step (2 weeks); (b) initial step (2 weeks) and (c) experiment for about 10 weeks.

Local male sheep were received grass field as primary feed, vary additional feed (concentrate, wet tofu cake and dried tofu 
cake) and water using ad libitum method. Dried tofu cake was made using fresh tofu cake which needs to dry in the oven $\left(110-170^{\circ} \mathrm{C}\right)$ for about \pm 10 hours. Wet tofu cake prepared by 15 min natural wind drying before supplied to the sheep. Feed composition were based on dried weight of feed or $3 \%$ from the weight of local male sheep and the additional feed were $30 \%$ from the total dried weight of feed. Additional feed were supplied 2 times a day, at 08.00 am and $03.00 \mathrm{pm}$, meanwhile the grass field were supplied 2 hours later.

The experiment was conducted using completely randomized design with 3 different treatments and 5 times repetition; $\mathrm{T}_{0}=$ ad libitum grass field + commercial concentrate, $\mathrm{T}_{1}=$ ad libitum grass field + wet tofu cake, $\mathrm{T}=\mathrm{ad}$ libitum grass field + dried tofu cake. The following parameters were taken to investigate the effect of tofu cake addition on the sheep feed; water consumption, body temperature, pulse, and rate of exhalation. Data analysis was done using analysis of variance (ANOVA) followed by Duncan's multiple range test.

Water consumption can be count from the difference of water supply with water remain in the cage per day. Rate of exhalation can be analyzed by perceiving the motion of the gastric frequency (flank) in $1 \mathrm{~min}$ period with 3 times repetition (times/min). Pulses were analyzed by perceiving it on neck in $1 \mathrm{~min}$ period (times/min). Body temperature was analyzed by using clinical thermometer in sheep rectal for about $3 \min \left({ }^{0} \mathrm{C}\right)$.

\section{RESULT AND DISCUSSION}

Feeding tofu cake (primary dried tofu cake) as additional feed for local male sheep gives a significant increment on the water consumption $(\mathrm{P}<0.01)$. Table 1 shown local male sheep's water consumption data during experiment conducted.

Data experiments shows that dried tofu cake as an additional feed $\left(\mathrm{T}_{1}\right)$ successfully increase the local male sheep's water consumption compared with the other two treatment $\left(\mathrm{T}_{0}\right.$ and $\left.\mathrm{T}_{2}\right)$. Water consumption of local male sheep of $\mathrm{T}_{2}$ was the lowest, due to wet tofu cake itself already containing up to $81.86 \%$ of water. The water contained in additional feed (wet tofu cake) fulfils almost all the water needed by local male sheep; therefore the sheep consume lack of additional fresh water. If there were water content in feed or additional feed, the sheep will need less water than usual due to sheep can absorb the water from any source include feed or additional feed to fulfil their water needed [15].

Local male sheep of $\mathrm{T}_{1}$ have higher water consumption data from the local male sheep treated by commercial concentrate $\left(\mathrm{T}_{0}\right)$. That was occur due to the local male sheep treated by dried tofu cake $\left(\mathrm{T}_{1}\right)$ consume more dried matter than sheep treated by commercial concentrate $\left(\mathrm{T}_{0}\right)$. Cattle need more water for several functions, such as: (i) as media for transporting substances contained in feed to intestine and moreover to the body in line with blood circulation; (ii) to dissolved substances that cannot spontaneously adsorbed by the body of cattle [13].

The exhalation rate of the local male sheep used in this research as shown in table 2 approximately 24 up to 40 times/min. The value still normal and meet the standard, since the exhalation rate of the local male sheep usually about 26 up to 32 times/min [17] or 20 up to 50 times/min [18]. According to above, the effect of replacing the additional feed from commercial concentrate to tofu cake, didn't found significantly. The key parameters which influencing the rate of exhalation are size of the body, age, activity, environmental temperature, feed quantity in digestion organ and body condition [17]. Moreover the rate of exhalation can change every time depend on the condition of the cattle in that time [17].

TABLE 1

WATER CONSUMPTION AVERAGE OF THE TREATED LOCAL MALE SHEEP USING ADDITIONAL FEED VARIANT (COMMERCIAL CONCENTRATE; WET TOFU CAKE; DRIED TOFU CAKE)

\begin{tabular}{ccc}
\hline Treatment & $\begin{array}{c}\text { Additional feed } \\
\text { consumption } \\
\text { (dry weight) } \\
\text { (g/d) }\end{array}$ & $\begin{array}{c}\text { Water } \\
\text { consumption } \\
(\mathbf{m l} / \mathbf{H e a d} / \mathbf{d})\end{array}$ \\
\hline $\mathrm{T}_{0}$ & 611.9 & $593.57^{\mathrm{a}}$ \\
$\mathrm{T}_{1}$ & 676.9 & $903.50^{\mathrm{b}}$ \\
$\mathrm{T}_{2}$ & 575.7 & $356.88^{\mathrm{c}}$ \\
\hline $\mathrm{a}, \mathrm{b}, \mathrm{c}$ row means with different superscripts differ significantly at $P<0.05$
\end{tabular}

Water consumption of cattle governed by several factor such as environmental condition, cattle's activity, type of feed and water quality. Other literature said that the main factor that contributes in the water consumption of cattle is environmental condition such as room temperature, the air humidity and sun light [16]. According to the above factor, the quantity of water needed by local male sheep difficult to determine, so the provision of water should be done using adlibitum method.

The replacement of additional feed from commercial concentrate to dried/wet tofu cake did not give a significant influence to the physiological response of the local male sheep. The physiological response data of local male sheep after treated by $\mathrm{T}_{0}, \mathrm{~T}_{1}$ and $\mathrm{T}_{2}$ summarized in Table 2, 3 and 4 .

TABLE 2

THE AVERAGE OF EXHALATION RATE OF LOCAL MALE SHEEP TREATED BY REPLACEMENT OF ADDITIONAL FEED FROM COMMERCIAL CONCENTRATE TO TOFU CAKE

\begin{tabular}{ccccc}
\hline $\begin{array}{c}\text { Treat } \\
\text { ment }\end{array}$ & $\begin{array}{c}\text { Morning } \\
\text { (times/ } \\
\text { min) }\end{array}$ & $\begin{array}{c}\text { Noon } \\
\text { (times/ } \\
\text { min) }\end{array}$ & $\begin{array}{c}\text { Afternoon } \\
\text { (times/ } \\
\text { min) }\end{array}$ & $\begin{array}{c}\text { Average } \\
\text { (times/ } \\
\text { min) }\end{array}$ \\
\hline $\mathrm{T}_{0}$ & 25.98 & 36.09 & 33.71 & 31.93 \\
$\mathrm{~T}_{1}$ & 27.15 & 40.02 & 38.95 & 35.37 \\
$\mathrm{~T}_{2}$ & 23.68 & 30.44 & 29.82 & 27.98 \\
\hline
\end{tabular}

Table 3 show the average of local male sheep treated by replacement of additional feed from commercial concentrate to tofu cake. The average of pulse of the treated local male sheep by $T_{0}, T_{1}$ and $T_{2}$ is slightly different in every the observation time. Rate of pulse was influenced by body temperature and exhalation rate [19]. Local male sheep in normal condition is having 63-90 times pulse rate/ $\min$ [18] or other state that about 70-90 times pulse rate/min [14]. Local male sheep pulse during the experiment conducted is $71-82$ times/min. Slight differences between the treated local male sheep by $\mathrm{T}_{0}, \mathrm{~T}_{1}$ and $\mathrm{T}_{2}$ indicate that the provision of tofu cake as an additional feed has no effect in local male sheep metabolism. 
TABLE 3. THE PULSE AVERAGE OF LOCAL MALE SHEEP TREATED BY REPLACEMENT OF ADDITIONAL FEED FROM COMMERCIAL CONCENTRATE TO TOFU CAKE

\begin{tabular}{ccccc}
\hline $\begin{array}{c}\text { Treat } \\
\text { ment }\end{array}$ & $\begin{array}{c}\text { Morning } \\
\text { (times/ } \\
\text { min) }\end{array}$ & $\begin{array}{c}\text { Noon } \\
\text { (times/ } \\
\text { min) }\end{array}$ & $\begin{array}{c}\text { Afternoon } \\
\text { (times/ } \\
\text { min) }\end{array}$ & $\begin{array}{c}\text { Average } \\
\text { (times/ } \\
\text { min) }\end{array}$ \\
\hline $\mathrm{T}_{0}$ & 72.97 & 82.39 & 77.72 & 77.56 \\
$\mathrm{~T}_{1}$ & 71.45 & 81.18 & 79.18 & 77.27 \\
$\mathrm{~T}_{2}$ & 74.86 & 81.83 & 81.07 & 79.25 \\
\hline
\end{tabular}

Statistics analysis result indicate that the effect of all treatment (replacing additional feed) for local male sheep remain the same $\left(\mathrm{T}_{0}, \mathrm{~T}_{1}\right.$ and $\left.\mathrm{T}_{2}\right)$ in every observation time. Table 4 shows the body temperature average of local male sheep treated by replacement of additional feed from commercial concentrate to tofu cake.

TABLE 4

THE BODY TEMPERATURE AVERAGE OF LOCAL MALE SHEEP TREATED BY REPLACEMENT OF ADDITIONAL FEED FROM COMMERCIAL CONCENTRATE TO TOFU CAKE

\begin{tabular}{ccccc}
\hline \multirow{2}{*}{ Treatment } & $\begin{array}{c}\text { Morning } \\
\left({ }^{0} \mathrm{C}\right)\end{array}$ & $\begin{array}{c}\text { Noon } \\
\left({ }^{0} \mathrm{C}\right)\end{array}$ & $\begin{array}{c}\text { Afternoon } \\
\left({ }^{0} \mathrm{C}\right)\end{array}$ & $\begin{array}{c}\text { Average } \\
\left({ }^{0} \mathrm{C}\right)\end{array}$ \\
\hline $\mathrm{T}_{0}$ & 38.53 & 38.72 & 38.87 & 38.71 \\
$\mathrm{~T}_{1}$ & 38.57 & 39.01 & 38.97 & 38.85 \\
$\mathrm{~T}_{2}$ & 38.45 & 38.84 & 38.78 & 38.69 \\
\hline
\end{tabular}

At normal condition, body temperature of local male sheep is in the range of $37.5-40.5^{\circ} \mathrm{C}$ [17], or other literature state in the range of $39.1-39.9^{\circ} \mathrm{C}$ [18]. Meanwhile, local male sheep body temperature during the observation time is in the range of $38.45-39.01^{\circ} \mathrm{C}$, it means that treated local male sheep can maintain their body temperature. Sheep is warm blooded cattle and able to maintain their body temperature in every condition. Sheep is also homoeothermic animal, that able to adjust the body temperature with the environment temperature [20].

\section{CONCLUSION}

Tofu wastes are a relatively cheap feed resource, considering their nutritive value. The provision of dried tofu cake as an additional feed replacing commercial concentrate was able to increase the local male sheep water consumption. It is also can be state that the provision of tofu cake does not cause physiological disorder to local male sheep.

\section{REFERENCES}

[1] Karossi, A.A., Sunardi, L.P.S. Patuan, and A. Hanafi. 1982. Chemical Composition of Potential Indonesian Agroindustri and Agricul tural Waste Materials for Animal Feeding, Feed Information and Animal Production. Proceeding of the $2^{\text {nd }}$ Symposium of the International Network of Feed Information Centers. Eds. : G.E. Robardsand LG. Packlam.
[2] Bondi, A.A. 1987. Animal Nutrition. John Wiley and Sons, Ltd., Chichester.

[3] Van Soest, P.J. 1994. Nutrition Ecology of the Ruminants. 2nd Ed. Cornell University Press, Ithaca.

[4] Hasnudi. 2004. The relative growth of the commercial carcass cutting of putih river and Local Sumatem sheep fed on palm oil by-product. Pengembangan Peternakan Tropis, 29: 115-120. (in Bahasa Indonesia)

[5] Ginting, S.P., LP. Batubara, A. Tarigan, R. Krisnan and Junjungan. 2004. Utilization of processing by product of white radish root (Raphanus sativus) as feed supplement for goats. Proceeding Seminar Nasional Teknologi Peternakan dan Veteriner 2004. 421-426. (in Bahasa Indonesia)

[6] Huda, R.N., 2005. The effect of tempeh contained in feed to local male sheep performance. Agriculture Animal Faculty, Sebelas Maret University. http://digilib.uns.ac.id/abstrak 7646 search on: June 13, 2011, 11:00 am.

[7] Chiou, P.W.S., Chen, C.R., Chen, K.J., Yu, B., 1998. Wet brewers' grains or bean curd pomace as partial replacement of soybean meal for lactating cows. Animal Feed Science and Technology. 74, 123-134.

[8] Amaha, K., Sasaki, Y., Segawa, T., 1999. Utilization of tofu (soybean curd) by-products as feed for cattle. FFTC Publication. www.agnet.org/library/eb/419 search on: June 13, 2011, 11:00 am.

[9] Hernaman, I., Budiman, A., Rusmana, D., 2010. Silage from tofu cake and onggok: production and their effect on the ferment ability and nutrient content. Agriculture Animal Faculty, Padjadjaran University. www.pustaka.unpad.ac.id/wp.../ search on: June 13, 2011, 11:00 am.

[10] Rojik, 2010. The effect of mixed feed (bran and soybean curd flour) in rabbit's fed consumption and body weight. Department of Animal Husbandry, Muhammadiyah Malang University- studentresearch.umm.ac.id (in Bahasa Indonesia).

[11] Tanwiriah, W., Garnida, D., Asmara, I.Y., 2005. The effect of tofu cake contained in feed to Muscovy duck performance at growing stage. Agriculture Animal Faculty, Padjadjaran University. www.pustaka.unpad.ac.id/archive/8728 search on: June 13, 2011, 11:00 am.

[12] Adrian, D., 2005. The effect of tofu waste in the diet on the protein: digestibility coefficient, retentionand net utilization of mature female Tegal duck. Agriculture Animal Faculty, Diponegoro University. eprints.undip.ac.id/4523/1 search on: June 13, 2011, 11:00 am. (in Bahasa Indonesia)

[13] Siregar, S.B., 1994. Ruminant Feed. Penebar Swadaya, Jakarta, Indonesia. (in Bahasa Indonesia)

[14] Soerono, Trihadi, Subronto, Sudarmadi, Suparto, 1976. Physiological data of Indonesian domestic animals. Research Series Publication. Veterinary Faculty of Gadjah Mada University Indonesia. (in bahasa Indonesia)

[15] Tilman, A.D., Hartadi, H., Reksohadiprodjo, Prawirokusumo, S., Lebdosoekojo, S., 1991. Science of feed for cattle. Gadjah Mada University Press. Yogyakarta Indonesia. (in Bahasa Indonesia)

[16] Parakkasi, A., 1999. Nutrition and feed science of ruminant. Indonesia University Press, Jakarta Indonesia. (in Bahasa Indonesia)

[17] Sugeng, Y.B., 1985. Growing sheep. Penebar Swadaya, Jakarta, Indonesia. (in Bahasa Indonesia)

[18] Dukes, H.H., 1955. The physiology of Domestic Animals. $7^{\text {th }}$ Ed. Cornell University Press, Ithaca.

[19] Frandson, R.D., 1992. Cattle physiology and anatomy. Gadjah Mada University Press. Yogyakarta Indonesia (translated by B.Srigandono and K. Paseno). (in Bahasa Indonesia)

[20] Andersson, B.E., 1977. Temperature regulation and environmental physiology. In: Swenson, M.J. (Editor). Duke's Physiology of Domestic Animals. $9^{\text {th }}$ Ed. Cornell University Press, Ithaca. pp. 686689. 